\title{
La basura como testimonio de la desubjetivación en Spam de Rafael Spregelburd
}

( Laura Gabriela Conde

CTCL-IdIHCS-Universidad Nacional de La Plata, Argentina

condelauragabriela@gmail.com

Fecha de recepción: 19/09/2017. Fecha de aceptación: 20/02/2018.

\begin{abstract}
Resumen
Este trabajo se propone revisar el tema del archivo y la construcción de la memoria como instancias claves del proceso de desubjetivación en Spam de Rafael Spregelburd. Los intentos de (re)construir una voz a partir de (sus) desechos (correo basura) y de los diversos artefactos tecnológicos y soportes que configuran esta subjetividad siempre mediada o diferida, nos conducen a pensar ambas nociones, por un lado, como dispositivos escénicos, esto es, indagar acerca de las relaciones intermediales en el teatro contemporáneo y la producción del dramaturgo específicamente; y, por otro lado, como problemas teóricos a partir de la figura del entre que atraviesa toda la pieza. Por tal motivo dedicaremos una parte significativa del análisis a las didascalias, que se configuran como intervalo y diferimiento entre el texto teatral y la puesta en escena, así como una interrupción intratextual.
\end{abstract}

\section{Garbage as Testimony to Desubjectivation in Rafael Spregelburd's Spam}

\footnotetext{
Abstract

In this paper we aim to analyze the issues of the archive and the construction of memory as key instances of the desubjectivation process in Rafael Spregelburd's Spam. The attempts to (re)build a voice from (its own) waste (junk mail/spam) and from the diverse technological artefacts and media that configure this subjectivitity, which is always mediated or deferred, leads us to consider both notions, on the one hand, as scenic devices -that is, to inquire about intermediality relations in contemporary theater and, especially, in the playwright's own production- and, on the other hand, as theoretical matters related to the figure of the "in-between", which is present throughout the whole piece. Therefore, we will dedicate a significant part of the analysis to stage directions, which are configured as interval and deferral between the theatrical text and the staging, as well as an intratextual interruption.
}

Palabras clave Spam; Spregelburd Basura; Archivo; Memoria; Desubjetivación; Intermedialidad
Keywords

Spam; Spregelburd; Archive; Memory; Desubjetivation; Intermediality 
Es importante que no todas las escenas de esta obra se vean: la fuerza de la información faltante, errática e indefinida, debe ser enorme para poder seguir esta historia con facilidad.

Rafael Spregelburd, Spam

Para llevar adelante el análisis de la obra en su dimensión textual y escénica contamos con el siguiente material de archivo facilitado por el dramaturgo, actor y director de la obra: la versión definitiva del texto antes de ser publicado, formato Word (con imágenes y ficha técnica del espectáculo incluidas) y un registro audiovisual editado de una función abierta al público.

\section{"Desaforadamente híbrida"}

Spam, "triste opereta apocalíptica" (Spregelburd en Ojeda, 2017) es una ópera hablada, escrita, dirigida y protagonizada por Rafael Spregelburd. En este género extendido en los países de habla germana, la Sprachoper, la música es proporcional al tiempo del texto y tiene tanto valor como lo dicho. La musicalidad de la escritura en verso y el ritmo de la palabra se complejiza con la composición experimental de Zypce y su ejecución en vivo (por ejemplo, en el trabajo con rimas libres e irregularidades en el ritmo). Como señala el autor, "el criterio de selección es prácticamente musical y no sólo argumental o temático" (Spregelburd, en Conde, 2013:70).

"Son aventuras dignas de James Bond. También traductores de Google, mafias pseudochinas en la isla de Malta, dudosos métodos para alargar el pene y falsos documentales suizos debajo del agua" (Spregelburd, en Bahamondes, 2015), comenta el mismo dramaturgo acerca de esta producción de la Fondazione Campania dei Festival, Napoli Teatro Festival Italia, Teatro Stabile di Calabria, Festival delle Colline Torinesi, TiConZero-Cagliari, coproducida en Argentina por el CETC y el FIBA 2013. Una pieza que resulta próxima al concepto de lo posdramático desarrollado por HansThies Lehmann (1999), si atendemos al tipo de estructura dramática que presenta, construida a partir del fragmento, la interrupción y la discontinuidad. ${ }^{1}$ Fondo y forma coinciden, pues la obra habla de la fragmentariedad del ser y sus discursos, pone en crisis las fronteras genéricas, y se sumerge en la búsqueda de nuevos modos de representación a partir de operaciones fundadas en la sinestesia (especialmente en el planteo multimedial de la puesta en escena y las imágenes poéticas que evoca el texto), la parataxis (una historia interrumpida, una cronología discontinuada, una subjetividad sin nexos subordinantes), la desestabilización de categorías y la desjerarquización de ciertos valores preciados para la cultura; operaciones que Lehmann identifica con las creaciones escénicas que tienen lugar a partir de las dos últimas décadas del siglo XX.

La estructura de Spam, que es -según advierte el propio autor- "desaforadamente híbrida" (Spregelburd, en Ojeda, 2017), presenta rasgos de la performance multimediática. En este sentido, es preciso remitirnos a la noción de intermedialidad que no sólo "designa los intercambios del arte teatral con los lenguajes, tecnologías, medios y dispositivos de la comunicación y el entretenimiento" (Pinta, 2012: 8), sino también investiga y experimenta sobre las posibilidades de tales interacciones y la diversidad de experiencias vitales que proponen los nuevos medios y tecnologías.Se sabe que los grandes medios de comunicación implican nuevos paradigmas artísticos, modos diferente de "representar(nos) la realidad, de acceder al mundo y percibirlo" (Cornago, 2004: 599), esto es, diferentes enfoques epistemológicos y de interrelaciones entre los sujetos de manera tal que en distintos momentos es posible registrar la primacía de una expresión artística por sobre las demás: primero el cine; a partir de los años sesenta, la televisión; luego el video y las comunicaciones en red del siglo XXI. Las últimas han construido un
1. Con este concepto Lehmann propone un marco analítico para la producción escénica contemporánea que afirma la autonomía del arte escénico respecto del drama, no como negación de éste ni del texto en sí sino como ampliación del campo de creación y redefinición del concepto mismo de drama. En Spam, el texto dramático no queda relegado respecto de otros elementos de la puesta en escena; por el contrario, veremos que sus modulaciones son centrales y están íntimamente articuladas con el espectáculo. Lehmann analiza las propuestas que ponen en crisis el drama burgués -donde se privilegia el aspecto literario por sobre el espectáculo- y las categorías aristotélicas o hegelianas del drama, a partir de búsquedas realizadas por creadores interdisciplinarios, desde Craig a Artaud, que exceden lo meramente textual. El concepto da cuenta de la permeabilidad entre las disciplinas artísticas y el carácter difuso de sus fronteras al definir un enfoque que hace posible incorporar en el estudio del teatro ciertos aportes de la poética, la teoría literaria, la dramaturgia, la filosofía, los estudios sobre cultura audiovisual, la antropología, los performance studies, entre otros, en el marco de la posmodernidad y las críticas a la posmodernidad. 
canon estético que podría aproximarse a lo teatral en cuanto a la apariencia de inmediatez, el ritmo performativo y fragmentario y la presencia cada vez más determinante del receptor (Cornago, 2004). Quizá lo más interesante sea que la propia obra expone el problema de las condiciones mediáticas de producción y recepción del arte, puesto que al desestabilizar las fronteras y las jerarquías entre alta y baja cultura, entre la producción y el consumo, se abre un nuevo repertorio de prácticas posmediales derivadas de la multiplicación de los canales y ámbitos mediáticos, dibujando un mapa abierto, descentralizado y desjerarquizado de las prácticas artísticas.

Cuando la teoría y la crítica teatral se refieren al creciente papel de las nuevas tecnologías digitales o numéricas en el ámbito del teatro, la danza y la performance, están pensando en la incorporación de proyecciones manipuladas digitalmente, el empleo de robots, tecnología telemática, realidad virtual, los MUDs, los MOOs, los videojuegos, los CD-ROMs y las obras de net.art, en el marco de una cultura visual. Pero las relaciones interartísticas no son prácticas novedosas, sino que constituyen "un componente básico del hecho teatral" (Abuín González, 2008: 33). Wagner ya lo había formalizado (antes Goethe, Schiller, Novalis) en la idea de obra total articulada en una multiplicidad de artes (danza, música, poesía, arquitectura, escultura y pintura). A propósito de esto, resulta interesante citar un fragmento de la entrevista que realizamos al dramaturgo, actor y director que nos ocupa (Conde, 2013). En esa oportunidad, le preguntamos si este procedimiento de llevar a la escena un material extranjero -en relación con lo que generalmente se espera de una obra teatral en el sentido más clásico-, se podría pensar como un principio constructivo frecuente en su producción, pensando en la estructura episódica de Bizarra como teatro-novela, la estética de El pánico, vinculada al cine, la trama de Acassuso o La escala humana, el tema de Bloqueo, Fractal, La modestia y $D K W$, basadas en todo un aparato teórico sobre los sistemas caóticos, la forma y la dialéctica; y si consideraba que tales formatos hacen hablar al teatro de otra manera. Así respondió:

Es verdad lo que señalás, sí, ¿pero por qué decir "de otra manera”, si el teatro siempre ha hecho esto? El teatro siempre supone un lugar de hibridación entre su técnica, su especificidad y otra cosa. Podemos pensar que en el teatro de Brecht esta otra cosa es la política, que en el teatro de Bob Wilson es la plástica y en el teatro de Shakespeare, la poesía (o también la política). Cuando el teatro sólo muestra los procedimientos del teatro yo creo que se empobrece, que sólo refiere a sí mismo. Si yo no tomo elementos ajenos me parece que no estoy escribiendo teatro. No es un movimiento demasiado consciente sino que trato de buscar la teatralidad de las cosas que me interesan, y las cosas que me interesan no suelen ser teatro, suelen ser otros asuntos" (Conde, 2013: 71).

Ahora bien, la intermedialidad del ámbito teatral se extiende en el teatro posdramático a los nuevos medios tecnológicos, insistimos, suprimiendo fronteras genéricas, generando materiales híbridos, a partir de nuevos modos de representación escénica. Abuín González (2008) habla de una intermedialidad sintética que busca la fusión de lenguajes procedentes de diferentes medios; una transmedial que nos pone ante funcionamientos de códigos y procedimientos que se encuentran en varios medios; y otra transformacional u ontológica por la cual se produce el trasvase de un medio a otro. La noción de "remediación" (imitación a partir de nuevos medios), comprende las operaciones de "hipermediación", que tiene como objetivo recordarle al usuario la utilización explícita del medio (y este grado de opacidad y manifestación explícita de la mediación es lo que encontramos en Spam), y la "inmediación", que intenta borrar la presencia del medio para que el espectador acepte la convención según la cual está de verdad ante los objetos representados (Abuín González, 2008: 36). Frente a las perspectivas tecnofílicas o tecnofóbicas que tienen una visión apocalíptica respecto del futuro del teatro ante al avance de las tecnologías de la escena, es preciso señalar 
que estas últimas no garantizan el acontecimiento teatral como experiencia estética. Es decir, el teatro sigue perteneciendo al territorio de lo inmediato y colectivo, a la co-presencia de intérpretes y espectadores más allá de las relaciones intermediales y diferidas que establezca; sin embargo, las artes escénicas pueden desestimar la experiencia vital asociada a las mediaciones tecnológicas. El teatro siempre se pregunta sobre su época, las condiciones de posibilidad de la palabra y su circulación, las imágenes de lo humano implicadas en las diversas miradas que se encuentran en un espectáculo y lo humano mismo como imagen configurado a partir de múltiples dispositivos. Desde los griegos, el teatro como técnica de la representación ha estado siempre abierto a los adelantos que le han permitido ampliar sus posibilidades de expresión y nunca detuvo su periplo en ningún punto que se considere el más elevado en tanto construcción de ese lenguaje o medio, sino que siempre continúa explorando sobre nuevas posibilidades. Es, por definición, un arte impuro.

Spam plantea una relación ambivalente con la tecnología y los medios de comunicación. Los presenta como dispositivos que llaman la atención sobre sí mismos formando parte fundamental de la trama; en otras palabras, su incorporación no está naturalizada ni fetichizada como sucede, en cambio, en la mayoría de los espectáculos que vemos en la cartelera porteña. El karaoke que se proyecta en una pantalla al comienzo de la puesta, instalando la escena en el sitio de lo que está para ser visto y -especialmente- escuchado por un público contemporáneo; la comunicación audiovisual vía Skype (grabada y no realizada en vivo); ${ }^{2}$ el formato de las bandejas de e-mail, resultan a nivel temático y dramático un arma de doble filo: el sujeto en cuestión sólo dispone de estos artefactos protéticos que prolongan el cuerpo en tanto que acciona y es a partir de esa conexión que lo enfrentan a la dispersión de la subjetividad y a la vez anuncian el fin del mundo en la era virtual.

Siempre con la distancia del humor, el cinismo o la ironía (a veces, incluso, paradójicamente cargada de afectividad), el pastiche que realiza en la mímesis de registros y gramáticas diversos, roza por momentos la parodia y dirige críticas no sólo a los medios de comunicación y a los usos de la tecnología, sino también al empleo de estos medios en el teatro (a cierto teatro que se dice interactivo y trata de ocultar sus relaciones de mediación, su carácter artificial, con el fin de hacerse pasar por experiencia real). Esto se puede observar no sólo en varios pasajes del texto, sino también en decisiones escénicas tales como la mala calidad de la imagen de los videos que se proyectan, el tono del pseudodocumental y las noticias de la televisión (grabaciones realizadas especialmente para la pieza con un evidente trabajo de posproducción) o la visualidad y organización discursiva del powerpoint y de Youtube. La incorporación del medio televisivo (las noticias) y la conexión en red destacan el carácter teatral o performativo de tales formatos: un ritmo rápido y entrecortado, la sensación de cercanía, casi de intimidad e inmediatez, en vivo y en directo, la presencia explícita del público y su aparente carácter colectivo (Cornago, 2004).

Los nuevos medios rompen la idea de unicidad o individualización de la obra de arte, así como también la noción de sujeto cartesiano, cognoscible, coherente y acabado; señalan, por el contrario, la dispersión y fragmentación propia del sujeto al mismo tiempo que toman distancia de las lógicas narrativas tradicionales. Ponen en crisis al teatro como evento único e irreproducible a partir de la irrupción de prácticas escénicas que no trabajan con la co-presencia simultánea de actores y público, sino que implican acciones grabadas o la telepresencia visual. El teatro virtual es -sostiene Abuín González (2008)remediado, inmersivo e interactivo, puesto que su contenido es el propio medio y, a la vez, su relación con otros medios. En la realidad aumentada o estéreo que se configura en la escena tendría lugar una hiper-realidad donde se superponen la realidad actual de las apariencias inmediatas y la realidad virtual de las mediáticas. Sin embargo, es preciso señalar que cuanto más tecnología se emplea, se advierte una mayor necesidad
2. Sería un ejemplo que evidencia que el director emplea este recurso como cualquier otro artificio escénico. No le interesa, en cambio, incorporar una comunicación real por Skype con una actriz que lo ejecute en vivo desde un espacio extraescénico y es precisamente el aspecto ficticio y no inmediato, sino siempre desfasado, el que predomina en las relaciones intermediales de Spam. 
de cuerpos portadores de palabras en relación con el espacio, los objetos, el presente de la escena. Son órdenes perceptivos tan diversos que el espectador debe hacer un esfuerzo por acomodar su ojo y su escucha ante tantos estímulos diferentes; sin perder de vista, además, que la imagen siempre le gana al cuerpo vivo en tanto forma más perfecta, acabada y verosímil, a la que nada perturba ni interrumpe (el espectador puede complacerse en su contemplación sin que peligre el acto estético). Spregelburd conoce muy bien estos problemas, por eso propone tal divergencia ontológica, escenifica la mezcla y el cachivache audiovisual al que estamos expuestos constantemente en la cotidianidad, reforzando las potencialidades de la materialidad de la escena a nivel sonoro y visual. En su obra el cuerpo excede los modelos y realidades preconfiguradas, o al menos se les resiste. Al ponerlo en tensión con la virtualidad, siempre en un proceso continuo de composición y descomposición, el cuerpo señala -para decirlo en palabras de Rubén Szuchmacher- la incapturabilidad de la puesta en escena (Szuchumacher, 2015), su carácter único, efímero y acontecimental.

Lo que queremos expresar con lo antedicho es que Spam nos hace ver la mirada construida por estos soportes de mediación y sus relaciones, los modos de percepción, y no los medios en sí (así como en Bizarra, el autor trabaja con el formato teatronovela y en varias producciones incluye videos, micropelículas, o emplea procedimientos provenientes del cine). Este es el aspecto más político de su teatro (más allá de las cuestiones políticas, sociales y culturales que se abordan en sus textos), puesto que efectúa una crítica inmanente a partir de sus propias formas y habla de los trasfondos que articulan las realidades, sus ritmos y modos de representación. Su mirada descreída revela "el teatro mediático que se esconde detrás de cada medio y la puesta en escena de la mirada cómplice que lo sostiene" (Cornago, 2004: 608), por medio del trabajo con la palabra poética (tonos, registros, estructuras discursivas) y las gramáticas de la tecnología. Perfila así relaciones que desautomatizan la mirada frente a lo conocido y, en consecuencia, revela la diferencia o espaciamiento abierto por ese cruce, que es el lugar por excelencia del espectador. En este sentido nos interesa destacar que Spam no trabaja el archivo ni las referencias al entorno contemporáneo como mera representación de lo real, sino como "cita a la supuesta realidad" y sus sistemas de interpretación. Así lo expresa el dramaturgo:

(...) muchas veces el público cree que su función es simplemente adivinar qué significan las referencias culturales que se le ofrecen como pistas de un policial que es el mundo. Algo que puede resultar muy aburrido, sobre todo cuando esas referencias están globalizadas, o son las mismas que difunden las noticias, las redes sociales, el sentido común. Me gusta ensayar en mis obras algo que imagino como la "organicidad pura de la biología": algunas cosas ocurren como pistas de otras, otras son simplemente catástrofes, y a veces las causas no preceden a los efectos. En SPAM esto se obtiene mediante un sencillo procedimiento técnico: las escenas se ven en total desorden, y al atacar la flecha del tiempo, causas y efectos se muerden la cola de una manera al menos escandalosamente divertida. Pero hay otros procedimientos, que también ensayan mis obras recientes: varias causas distintas para un mismo efecto; o causas sin efecto futuro que aparecen ligadas a efectos sin ninguna causa aparente en el pasado. Son intentos de plasmar algo del funcionamiento de la realidad más allá del ordenamiento que de ella haga la razón (Spregelburd, en Ojeda, 2017).

La obra se estrenó cuando el calendario maya llegaba a su fin -comenta el autor-, la economía mundial tambaleaba, se alzaba el terrorismo global, la especulación financiera había vaciado varios países y la crisis europea preanunciaba un fin del mundo muy concreto en Italia, en Portugal, en Grecia o en España. Fue escrita por encargo para "engalanar la ridícula crisis sociopolítica italiana del fin de la era berlusconiana". No obstante, los universos que evoca trascienden estos tópicos combinando elementos tan 
disímiles como el hundimiento del Costa Concordia, la muerte y exilio de Caravaggio, una muñeca mecánica ensamblada en China que dice malas palabras, la extinción de una lengua antigua de la Mesopotamia asiática, la crisis ecológica producida por la acumulación de la basura (real y virtual) y "un sinfín de episodios de este comienzo de milenio que se ha despertado muy estúpido" (Spregelburd en Ojeda, 2017).

La constitución de la voz del protagonista y los procesos de desubjetivación que analizaremos, se superponen con la configuración de la voz del director y del actor que, además de interpretar a Monti, vocaliza al performer o a un artificio de sí mismo, no como subjetividad ni persona empírica, sino como centro por donde pasa el espectáculo, es decir, como figura que domina lo que se dice, se escucha y se ve en escena. El cuerpo del actor o practicante escénico "no es sólo una presencia material que ejecuta una partitura performativa dentro de un marco referencial y estético", sino el de un "sujeto inserto en una coordenada cronotópica" que asume la "eticidad del acto y las derivaciones de su intervención", una política de la presencia (Diéguez, 2007: 45).

\section{"Es apenas un niño, fugaz, que me saluda"}

Presentaremos una selección de textos a cargo de Monti u otras voces (palabras efectivamente pronunciadas en la puesta en escena), concentrándonos en los ejes propuestos: archivo y memoria. A continuación registramos ciertas menciones a personalidades o acontecimientos históricos, con el fin de analizar de qué modo lo documental cobra relevancia en el nivel temático y también de los dispositivos escénicos empleados. Ya en Apátrida (2011) Spregelburd incorporaba las cartas casi originales de Auzón y Schiaffino (una de ellas, de puño y letra del propio Schiaffino, se proyectaba al final), con algunas intervenciones para ajustar la métrica y lograr que fuese más envolvente su escucha, así como también exagerar su retórica y reflexionar sobre un tipo de lenguaje perdido. El autor afirma que los anacronismos funcionaban como "efectos de distanciamiento muy explosivos", y que la incorporación de los documentos (la cartas, los recortes de diario) no sólo le daba un marco verosímil a la historia -con un gesto evidentemente fetichista- sino que, sobre todo, destacaba la "vigencia escandalosa" de los acontecimientos que efectivamente tuvieron lugar en nuestro país (Spregelburd en Conde, 2013: 71 y 74).

Tomamos dos casos de Spam: Caravaggio y Monti. El primero es la cita al cuadro "La decapitación de San Juan Bautista" de 1608. Su extensión obsesiva al nombre del hotel en el que se hospeda el protagonista funciona como una suerte de anti-pista que aparenta relacionar hechos cuando en realidad no conduce a ninguna trama posible (o mejor, visible), pues las correspondencias son menos anecdóticas y más profundas o secretas. Así, la historia del pintor se vincula con el extraño periplo de Monti. Cuando visita la Catedral de La Valletta, en Malta, ve la pieza que Caravaggio pintó durante su exilio en la misma isla para agradecer la discreción y el asilo de los Caballeros. Según Monti, el pintor había matado a un hombre en un confuso episodio con una pelota. Este motivo abre una red semántica que recorre el texto de principio a fin (el exilio, el crimen, el hundimiento en el mar, la extinción de todo lo que ingresa en el relato del tiempo); isotopía que se ve resignificada por otros discursos o medios de expresión, como ocurre en el caso de la transposición de la escena de la decapitación representada en la pintura a una imagen de un crimen en un supermercado chino donde se reproducen varios elementos del Caravaggio (ambas imágenes se proyectan en pantalla durante el espectáculo). Este tipo de relecturas, además del logrado e inquietante efecto cómico, corroe cualquier tipo de umbral entre lo alto y lo bajo, el arte y el consumo, lo sagrado y lo banal. Consideramos, además, que la elección de este artista barroco ${ }^{3}$ produce un nuevo sentido en relación con un gesto común a ambos creadores: Caravaggio a menudo incorporaba en su tela asuntos subvalorados como materia prima
3. Recordemos que la transposición de una obra plástica a la dramaturgia y la puesta en escena, no sólo como tema o procedimiento de escritura sino también como fundamentación teórica y estética, es una práctica habitual en la producción del autor. Ya en su Heptalogía de Hieronymus Bosch, que nació a mediados de la década del 9o, Spregelburd retomaba Los siete pecados capitales y las cuatro Postrimerías del pintor flamenco del siglo XV conocido como El Bosco. 
de las obras de arte -que evidentemente ultrajaban el fresco histórico y su elocuencia-, junto a ciertos arquetipos o mitos tradicionales de la cultura occidental. Cuando DidiHuberman se cuestiona acerca de cómo estar a la altura de todos los tiempos que una imagen conjuga en tantos planos, o de cómo dar cuenta del presente de la experiencia ante una imagen, propone una arqueología crítica de los modelos de tiempo, de los valores de uso del tiempo en la disciplina histórica que quiso hacer de las imágenes su objeto de estudio. Las imágenes son (y nos enfrentan a) un extraordinario montaje de tiempos heterogéneos que forman anacronismos (Didi-Huberman: 2011). Spam pone en funcionamiento este objeto de tiempo complejo, impuro, de manera espectacular; arma un sistema propio donde lo que parece mera coincidencia encuentra un funcionamiento para nada arbitrario, próximo al de las imágenes del inconsciente:

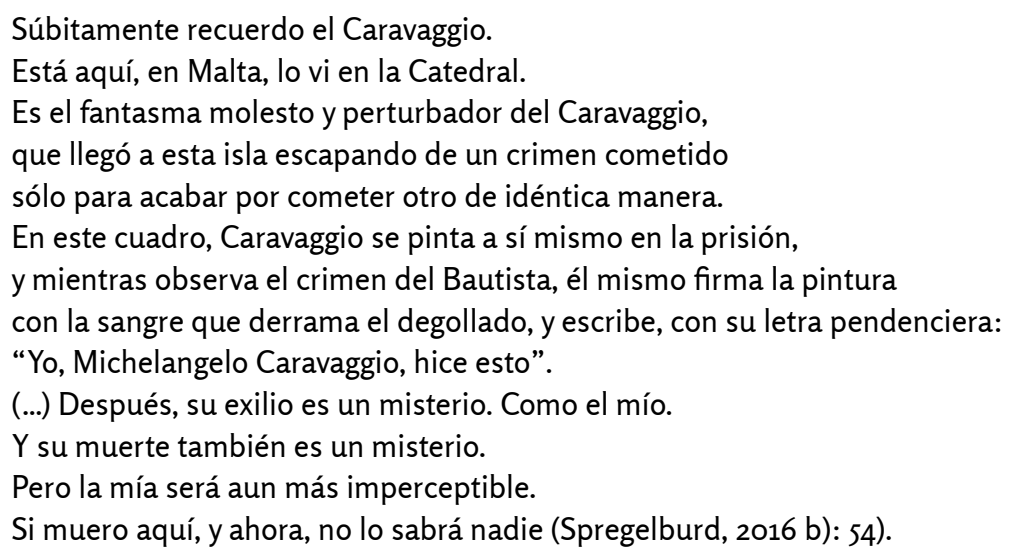

La historia es un procedimiento de construcción de realidad -no el único- que sigue la flecha del tiempo y que, por lo tanto, es el colmo del sueño de la razón, la asociación de causas y efectos en ese sentido estricto, explica el autor. El teatro sería entonces un instigador de la Historia, de las historias, porque permite cuestionar la razón de maneras diversas, por ejemplo, al poner en primer plano la emoción o la contradicción del individuo por encima de su pertenencia a una "razonable comunidad de sentido común". Siempre el teatro, ya que se ejecuta ante una polis, un público, es político, e invita a debatir qué es lo que está pasando con $t u$ Historia. Por lo tanto "nunca es la historia de otros la que está siendo representada y si yo represento aquí un fragmento o episodio de la historia de Alemania, es pura y exclusivamente para confrontarlo y hablar del presente de estos espectadores argentinos" (Spregelburd en Conde, 2013: 72-73). Nos interesa leer en esta dirección las referencias a Mario Monti, el Primer Ministro de Italia, teniendo en cuenta que la obra fue escrita por encargo para que la protagonice el actor italiano Lorenzo Gleijeses.

Una alumna, Cassandra, le cuenta al protagonista -catedrático que se especializa en el estudio de lenguas muertas- que la universidad está cerrada porque el Ministro ha sufrido un atentado. Este episodio se superpone con la búsqueda de la propia identidad por medio de un procedimiento típicamente borgeano: su nombre coincide con el del Primer Ministro. Cuando quiere buscar información sobre su identidad, todas las entradas están vinculadas al funcionario. Recupera aquí los discursos que han circulado respecto de ese hecho en los medios:

Monti está vivo. Tres de sus mejores guardaespaldas aparecieron en la Fontana di Trevi boca abajo con el estómago relleno de piedras y de brea. Lo adjudican a un ajuste entre mafias nacionales o a una muestra de indignación popular pero anarquista ante el anuncio de los próximos recortes en Italia (53). 
Luego de un reinado de ignominia berlusconiana -comenta Spregelburd-, el pueblo italiano (harto ya de eso que se le presentaba como política en su contexto), ve a Mario Monti asumiendo el poder provisorio de lo que quedaba del Imperio Romano. El nombre de este tecnócrata y gerente desconocido que -a los ojos del pueblo- era el único capaz de comprender la crisis bancaria y responder a las órdenes de la Europa Central, coincide con el de este personaje que pierde la memoria y despierta en un hospital de la isla de Malta con no mucho más que su pasaporte. "Así son las cosas: llamarse Mario Monti, o José Pérez, puede ser letal en el cybermundo" (Spregelburd en Ojeda, 2017). A Monti le resulta "absurdo" que su nombre no le diga nada; al googlearse descubre que la designación del Ministro borró los registros asociados a su nombre. ${ }^{4}$ Así comienza una investigación en la que borrar (o ser borrado) es condición de la escritura (o de escribirse), y el olvido, condición de la memoria. Se pregunta: ¿Y yo?/¿Y los otros Marios Montis? (25).

En una segunda instancia seleccionamos fragmentos relevantes en función de los asuntos que nos ocupan: la subjetivación/desubjetivación, la memoria, lo que resta, la extrañeza de ser, el archivo, la concepción del tiempo. En su día diez en la isla, Monti viste un smoking usado; el encargado del hotel le dijo que llegó en ambulancia con un golpe en la cabeza. Parece que una enfermera encontró su pasaporte y una tarjeta del hotel como señalador del libro El extranjero de Camus en sus bolsillos. Con este episodio y la remisión -casi grotesca- a este libro clásico del existencialismo se abre una cadena de términos asociados: exilio, amnesia, extraño, ajeno, indefinido, extranjero, sin valija, sin pasado. También lleva consigo una laptop y cajas llenas de muñecas, pero lo único que verdaderamente tiene es conexión, como el Krapp de Beckett que escucha y graba en una última cinta un relato fragmentario de sí mismo (se trata de la grabación de un diario en un magnetófono). El cuerpo de Krapp, su voz, se prolongan en una serie de artefactos que funcionan como prótesis de la subjetividad en tanto que dan soporte a una biografía apócrifa que se cataloga en cintas, se ficha y se numera en cajas, con la pretensión de registrar lo incuantificable de la experiencia (Conde, 2016). Esos fragmentos de ser se reúnen y agolpan de manera contigua (no continua) como los días de Monti en su calendario enloquecido. En la obra de Beckett, también el problema de la subjetividad se entrecruza con el tema del tiempo: "Recuerdo el año transcurrido", dice Krapp, e inmediatamente alude a su "vieja mirada futura." Esta frase de Krapp condensa toda la obra, pues, quien dice $m i$ es un yo sido mañana (algo imposible, en principio, puesto que descalabra tanto la lógica lineal del tiempo como la misma gramática): un montaje de tiempos similar al que vive Monti, que también se pregunta quién es ese que dice yo. No obstante, algo acontece, algo peligra en esa interrupción que toda reconstrucción de un archivo o todo recuerdo supone. Lo trágico del presente es entonces mucho más que una revelación del pasado. Así, Monti trata de reconstruir su vida reciente visitando las páginas que guarda el historial de la PC, dispositivo protético de la era virtual por excelencia:

\section{Me conecto. Cassandra.}

Tengo tres mails suyos, todos ellos caratulados como "urgentes".

(...) Al parecer está ansiosa por que yo vea las nuevas correcciones en su tesis.

Es una pista. Debo ser su profesor.

Me tranquiliza. No explica el asunto del smoking

ni tampoco esto de las muñecas. Pero me siento a gusto

sabiendo que no soy un agente de Interpol

ni un prófugo, ni un loco. Aunque lo uno, me digo, no siempre excluye lo otro.

Hasta tanto me vuelva la memoria,

busco en mi bandeja de salida para ver qué le escribí yo a esta Cassandra.

Nada. Jamás le respondí.

(...) ¿Estoy solo? ¿Nadie más me escribe?

$¿ O$ yo mismo he eliminado todo deliberadamente,
4. En el espectáculo se proyectan fotografías del Ministro. Si bien la incorporación de la imagen en tanto documento genera un impacto visual diferente al de la pintura de Caravaggio o de otras imágenes que se proyectan, aquella se coloca sintácticamente al mismo nivel que las demás. De esta operación resulta una desjerarquización y acumulación caótica de elementos disímiles, aparentemente absurdos (disonantes), así como la reversibilidad o contaminación entre el plano de la ficción y el de la realidad. 
como un criminal que está borrando pistas?

Todo lo que queda en mi bandeja es el spam.

Siempre lo mismo: Agrande su pene (7).

Esta "publicidad obsesiva, monocorde" (Spregelburd, 2016 b: 8) se repite y, además de constituirse como procedimiento sonoro, bordea el núcleo de la obra: el correo basura que resulta completamente ajeno es, al mismo tiempo, el que define al sujeto en el mundo virtual, ya que los productos en principio insólitos que allí se promocionan se vinculan con sitios web que evidentemente en algún momento ha visitado. Monti no se reconoce en esa imagen que le trae la basura; tampoco recuerda haber hablado nunca con nadie de este tema. Cuando le pregunta al buzo suizo, un personaje que se encuentra en la isla, si no le resulta extraño que los hombres no hablen en público de eso y que, sin embargo, se les ofrezcan todo el tiempo cirugías, pastillas, ejercicios, se pone de manifiesto la trama archivo - basura - memoria - subjetividad:

¿Hay una vida social y otra que es privada,

en la cual uno debe comerse solo

todo el spam de su bandeja?

(...) "No sé", me dice. "No lo he pensado.

Borre el spam, borre todo. No abro los mails.

(...) ¿Borrarlo todo? (Spregelburd, 2016 b: 18)

Y aquí también resuena uno de los tópicos centrales de la obra que va desde la idea de "fortuna virtual" al modo en el que el propio mundo tiende a convertirse en una virtualidad. El protagonista permanece siempre a la espera de algo que no acontece: "cuando uno espera algo importante /todo es spam" (22). Espera ante todo que Cassandra desista de escribir su tesis y se ocupe de aclararle quién es, quién era, y en qué se ha convertido (32).

En el día 17, que se titula "La basura virtual", Monti revisa archivos y encuentra artículos presumiblemente suyos sobre la extinción de una antigua lengua muy poco flexible de la Mesopotamia, la lengua de los eblaítas. Las fuentes se han borrado, insiste; los pueblos antiguos y las arenas han devorado los rastros de esta lengua. Él se dedicó a reconstruirla, pero si se borra el disco duro de su PC, advierte, "se borrará por segunda vez, definitiva,/ la lengua desgarrada de este pueblo" (Spregelburd, 2016 b: 9). Y no hace copias justamente porque le gusta pensar que lleva consigo un tesoro. Se atesora y archiva la escritura que, como la identidad, está inevitablemente expuesta a la destrucción y al olvido. La existencia, nos dice Spam, no es más que el intento incesante y fracasado de reconstruir una memoria horadada. Cuando sale de la Catedral de Malta encuentra un libro de visitas y se decide a firmarlo. Piensa poner un nombre falso, porque el suyo ya no le dice nada, pero luego de una leve impresión táctil que le resulta familiar, encuentra su propia firma en trazo infantil. Se asombra de haber estado allí sin poder recordarlo y trata de imaginar a ese niño que no le trae más que incertidumbre:

¿Qué quise decirme al escribir este mensaje?

¿Dónde más me he dejado mensajes y por qué?

Leo esos garabatos de niño,

del niño que fui,

leo ese mensaje de alerta.

¿Qué hubo entre esas profecías y el presente?

No son profecías, me digo.

Es apenas un niño, fugaz, que me saluda (11).

El día 5 se envía una carta a sí mismo sospechando que no durará mucho en este exilio autoinducido. Firma con un nombre falso, Nicolino Monti, y la manda al hotel donde 
se hospeda. Luego aclara que se trata del nombre que su madre había pensado para él y decide dejar su regreso a casa "librado a las leyes del azar" (Spregelburd, 2016 b: 33). La postal dice: "Despierta. Ya es hora de volver a casa". Leit motive del diseño sonoro que palpita en un constante "me está por llegar" (Spregelburd, 2016 b: 33).

El día 22, buscando pistas, encuentra en el bolsillo interno del smoking unas instrucciones en inglés que -aparentemente- se escribió a sí mismo: "Pase lo que pase, no tocar los picaportes. /Están radioactivos. Recordarlo siempre" (Spregelburd, 2016 b: 52). Se pregunta qué significa, incluso, si esa letra es suya. Parecería que en el universo de Spam lo más extraño y absurdo es tratar de ser uno mismo, mientras que la no coincidencia, el desfasaje y la desubjetivación, se presentan como fenómenos naturales e ineludibles. La extrañeza de ser que experimenta Monti al despertar remite nuevamente al pensamiento existencialista, ahora resignificado por la virtualidad del spam que -estamos en condiciones de afirmar- se constituye como un estado del ser:

Lo más extraño del mundo me ha pasado.

Y es tan aterrador que espero no se asusten al oírlo.

Despierto como siempre, atormentado de tanta incertidumbre, he pasado un mes de spam. (Spregelburd, 2016 b: 67)

Las pistas quedan encerradas en el enigma; a veces los nombres desencadenan recuerdos "tan vívidos como probablemente falsos" (67); otras veces, el recuerdo tiene que ver con lo sensorial como ocurre en el tacto de los folios del libro de firmas, o la imagen de la lluvia que conecta episodios en los que se compone y evapora la subjetividad:

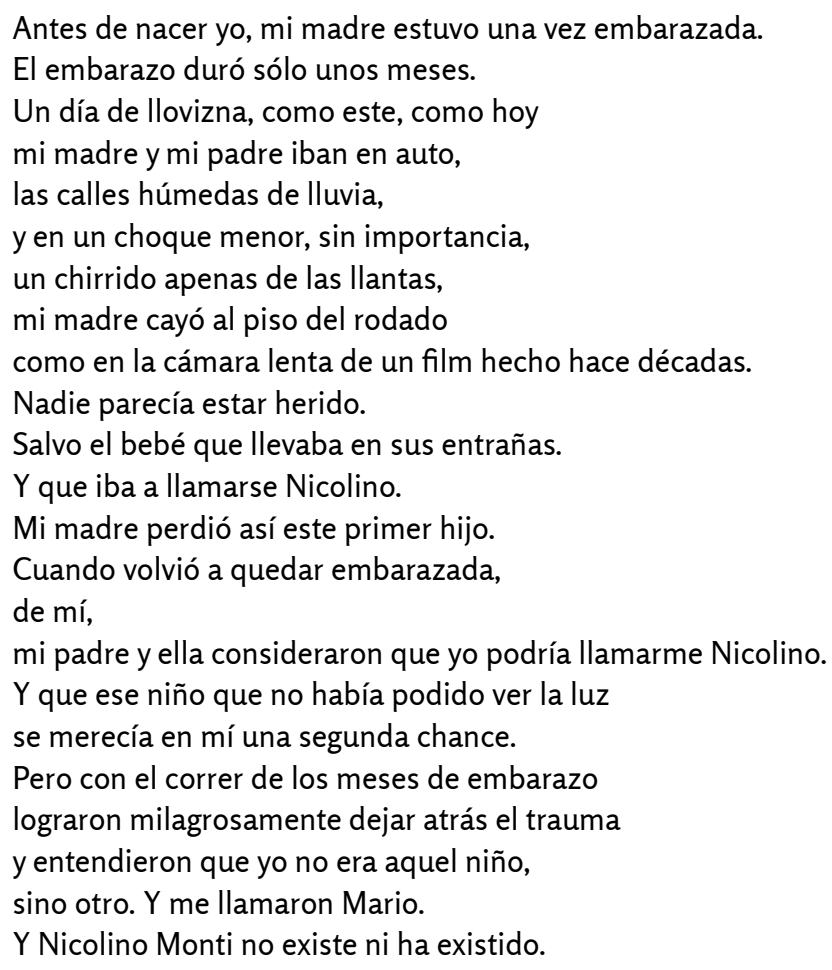

Sin embargo a veces creo ser yo.

¿Por qué no podría ser yo

el que hubiera muerto, y no él? (67-68)

Cuando se envía la carta a sí mismo firma con el nombre del niño que no nació. Como el spam, ese otro anterior, indescifrable, persiste aunque no sea posible acceder a algo más 
que su nombre ni recomponerlo como pasado. Entonces quien dice yo, Monti, arrastra su propio/otro excedente, un resto, un fantasma; y en esta lógica entra en juego la máscara, el disfraz, que vale lo mismo que el nombre: el traje de Connery que lleva puesto, según el protagonista, es la ropa que merece (35). Como algo de lo real siempre retorna, la concepción del tiempo que se configura en la obra es cíclica, anacrónica, funciona por repliegue o superposición de episodios. Es claro cuando se habla del tiempo de la cultura inuit o esquimal: "el presente es una repetición ritual de otra cosa, una celebración de eventos ya ocurridos en el pasado" (Spregelburd, 2016 b: 14). El mismo Monti lo vincula a las investigaciones de Freud sobre la psiquis humana y la relación traumática con los acontecimientos del pasado (14). Si una foca ha frecuentado un hoyo en el hielo en agosto del año que pasó, y si ha encontrado alimento en ese hoyo, es probable que vuelva en el invierno al mismo punto, mucho más gorda, en busca de más alimento. El tiempo es, para la foca, un resorte que aleja o acerca cosas parecidas. El inuit aunque tenga hambre, si es sabio, en vez de cazar a la foca la alimentará con un pescado. Para realizar tal sacrificio se fabrica una noción: la del tiempo; entonces invierte su pescado en tiempo. Más adelante Monti llega incluso a negar la existencia del tiempo: "Pero el tiempo en realidad no existe, ya lo vieron:/es mera administración del hambre" (Spregelburd, 2016 b: 15); frase que repiten las muñecas al final de la obra. A la vez, aparece el tiempo finito y la visión apocalíptica; en palabras del amigo agrimensor, mientras señala un calendario maya: "El mundo es breve y el tiempo está acabándose" (59).

\section{"La basura puede -a veces- ser muy cara"}

En este apartado anotaremos algunas reflexiones acerca del lenguaje, lo real, el arte y la experiencia. Un colectivo de artistas, con sede fluctuante en Internet, se adjudica un hecho criminal como obra artística: se trata de una intervención anónima sobre unos juguetes de alta tecnología y bajo costo. Alteraron las grabaciones de unas muñecas que hablan, fabricadas industrialmente, "sin alma, en serie y sin detalles," (Spregelburd, 2016 b: 39) mientras que las suyas se convierten en obra de arte puesto que recuperan el carácter único del objeto y provocan un efecto estético, un verdadero contacto con el público (que es muy reducido, porque no se produce en serie). Se trata de poner en cuestión el vínculo comercial del fabricante con el producto y el consumo, hecho que "preanuncia el Fin del Capital" (Spregelburd, 2016 b: 39). Compara esta declaración delictiva con la confesión del crimen de Caravaggio en Malta, pues ambos actos implicarían una autoafirmación "que endiosa la firma del artista" (Spregelburd, 2016 b: 39). Cita otra experiencia con bolsas vendidas como juguetes donde se intenta desestabilizar "la frontera anquilosada entre envase y contenido" (Spregelburd, 2016 b: 39), y demostrar así que un niño sabe jugar naturalmente con una caja de cartón pero que, por el contrario, debe aprender culturalmente a jugar con la Wii que viene en ella. Lo que al periodismo le resulta escandaloso es casi admirable para Monti, a quien lo apena que este grupo "I did it" no exista en ningún lado más que en el éter de la web (39). Y tal fascinación puede provenir también de la idea del arte como gasto, en los términos en que lo pensó Bataille, puesto que estas intervenciones convertidas en obra escaparían a cualquier lógica capitalista. ${ }^{5}$

Reflexiones de este tenor son muy frecuentes en la producción del dramaturgo, por ejemplo, en El fin del Arte o Apátrida. Esta última cierra la puesta en escena con el famoso hit "Panamericano", y en otra temporada, con "Gangnam style" (el baile del caballo). Una explicación temática elemental de esta selección sería la siguiente, según Spregelburd: si el triunfo del arte -como sostiene Auzón- es un elemento de alta portabilidad ("El arte no tiene nacionalidad sino una patria universal que es el mundo"), estaríamos frente a una obra de arte en el "Gangnam style". Un elemento absolutamente improbable cuestiona naturalmente la relación entre difusión, popularidad, el anclaje de la necesidad de los íconos y el pueblo, y surge la pregunta sobre la
5. Lo no rentable del arte y su carácter desquiciado respecto de cualquier pensamiento de índole positivista y capitalista, es pensado por Spregelburd como desmesura respecto de sus propias producciones: La estupidez, por ejemplo, "no fue económica. No fue razonable", (Spregelburd en Koss, 2016: 13) puesto que -más allá de las posteriores resoluciones escénicas que lograron cierta síntesis para que fuese realizable- duraba más de tres horas y media y estaba integrada por veinticuatro personajes. 
transnacionalización del arte y la levedad de sus raíces: "Si este es el destino del arte, su universalización hasta el nivel escandaloso de perder todos sus otros elementos y este es el triunfo del ideal de Auzón, estamos fritos" (Spregelburd en Conde, 2013: 76).

Vamos a detenernos ahora en el documental del día 14 sobre la lengua de los eblaitas, extensísima en palabras y singular por el uso de lo que hoy entenderíamos por la preposición entre, definida como aquello que designa el espacio entre un sustantivo y otro sustantivo. Por ejemplo, para decir que algo se encontraba entre una piedra ("tût") y una uva chinche ("genito"), se pretendía dar cuenta de las sensaciones linguales del "estar entre" ambos sustantivos; de allí surge la palabra "drevhir" (16). La repetición de esta palabra en el discurso de Monti -además del efecto cómico y teatral que hace que este texto sea una obra de ficción y no una tesis- empuja a la propia lengua hacia el límite de su imposibilidad para alcanzar la experiencia. Anotamos algunas interrupciones del "entre": "¿Cómo se dice el espacio entre una mesa ocupadísima/ y otra mesa con un solo cliente y un salero?/ ¿Cómo es... esa palabra?” (17); "En algún momento entre Nápoles y Malta,/ digamos que entre ayer y hoy (...)" (33); "entre un guiño y otro de los ojos azorados de la historia"; "Fuimos el sueño entre dos hielos" (37); "y nada en el aire,/ en el silencio,/ en el bullicio,/ nada en las palabras,/ nada entre ellas,/ nada en los huecos impalpables que dejaban,/ podía predecir esta tragedia" (68); y -no menos curioso- la fecha y el lugar que figuran al final de la obra es "Buenos Aires-Napoli, entre noviembre de 2011 y julio de 2013" (Spregelburd, 2016 b: 68).

Esta figura no sólo opera como principio constructivo y temático, sino que también lo hace como dispositivo de la puesta en escena; esto es, por ejemplo, que el entre se escenifica a partir del diferimiento de la imagen y el sonido. Es así como los huecos del pensamiento, de la memoria, de la lengua, se ponen al mismo nivel que los huecos de la tecnología. Monti nota que en la videollamada con Casandra la imagen va más lenta que el sonido; a veces se congela y él se inquieta porque "El silencio es peor que el delay" (53). "Estas cosas ocurren todo el tiempo" (Spregelburd, 2016 b: 26), expresa Monti, "Pero no siempre estamos mirando donde se debe" $(26) .{ }^{6}$ Nuestra hipótesis es que el entre impensado es justamente el sitio desde donde se debe mirar esa basura o resto, es decir, lo que no aparece en la superficie o se manifiesta de un modo incompresible para cualquier lógica racional. Y los dispositivos escénicos enfatizan estos pliegues o junturas (por tomar una noción lacaniana y derridiana) donde se acumula la basura, confusa y profusa: el traje de Bond, una pintura barroca, muñecas que hablan, una filmación subacuática, la mafia china. La basura es la primera industria del mundo tal como hoy lo concebimos y sostiene al capitalismo agonizante a partir de la producción de cosas inservibles, afirma Monti, y luego se pregunta:

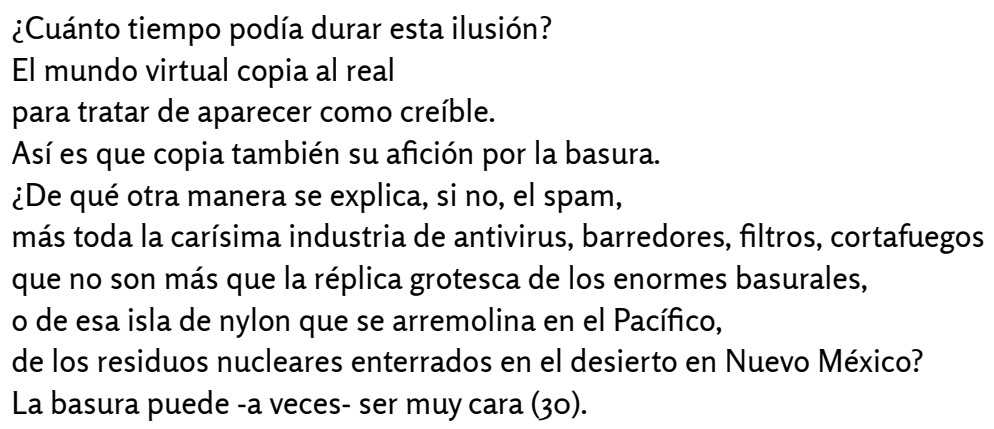

Proponemos leer este punto nodal de la pieza a la luz de la noción de "exforma" formulada por Nicolas Bourriaud (2015). Las cosas y los fenómenos, sostiene este teórico, parecen amenazarnos bajo la forma espectral de desechos recalcitrantes que no acaban de desvanecerse o que persisten después de su evaporación: "Vivimos en pleno exceso, entre archivos atestados, productos cada vez más perecederos, (...) mientras el
6. En el espectáculo este texto se lee por medio de una proyección mientras el actor se viste con un kimono. Además de desujetar la voz, puesto que lo que en el texto figura en boca de Monti aquí se manifiesta de manera impersonal y escrita, esta decisión escénica focaliza la atención en una frase que encuentra resonancias significativas en toda la obra. 
capitalismo se atreve a soñar con un mundo de transacciones 'sin fricción' en el que las mercancías, englobando con este término a los seres y a las cosas, circularían sin ninguna clase de obstáculo" (Bourriaud, 2015: 7-8). Esta reflexión podría ser proferida por el propio Monti, pues es el testimonio de una época caracterizada por el residuo energético, la toxicidad durable de los residuos nucleares, la saturación de las áreas de almacenamiento y los efectos dominó causados por los desperdicios industriales en la atmósfera o en los mares. Nuestra imaginación del residuo, sigue Bourriaud (2015), encuentra su expresión más fogosa en la economía; el universo de las finanzas parece invadido por productos nocivos, por materiales peligrosos que se entierran en los balances de oscuras sucursales o en carteras de inversión. En Spam se revela con claridad lo real del mundo globalizado, acosado por el fantasma de lo improductivo y de lo no-rentable, en guerra contra las personas y las cosas que permanecen fuera de la lógica del trabajo o no producen una idea de futuro más o menos palpable.

La esfera de lo residual ha crecido y tiene una historia. Lo que más nos interesa de este trayecto es su carácter fronterizo o de entre. Así lo explica Bourriaud: "La "ronda fantasmagórica" descrita por Karl Marx en El capital parece adquirir hoy un nuevo aspecto". Desde el siglo XIX, arte y política fueron moldeados por la fuerza centrifuga creada por la Revolución Industrial, que puede pensarse como un movimiento de exclusión social, por un lado, y un rechazo categórico, por el otro, de ciertos signos, objetos o imágenes. En el reinado del modelo de la termodinámica, la energía social produce un residuo, generando zonas de exclusión en las que se apiñan en completo desorden el proletariado, los explotados, la cultura popular, lo inmundo y lo inmoral: el conjunto subvaluado de todo lo que no se podría ver, señala Bourriaud. Esta ronda se basa entonces en el modo en el que se orquestan los vínculos regulados entre el centro y la periferia, en cómo se organiza la colisión entre lo oficial y lo rechazado, entre lo dominante y lo dominado, hasta hacer de la frontera el lugar mismo de la dinámica de la Historia (2015: 9-10). A partir del siglo XIX, las vanguardias políticas y artísticas trataron de hacer que lo excluido pasase del lado del poder, derrocar a la máquina termodinámica, capitalizar el rechazo al capital, reciclar los supuestos desperdicios para hacer con ellos una fuente de energía. La inversión del movimiento centrífugo consistió en llevar al proletariado hasta el centro, lo desclasado a la cultura y lo devaluado a las obras de arte. Si esta dinámica centrípeta produce aún energía y el arte recicla los restos caídos para representar al viviente, deberíamos admitir que la imagen de este viviente en la cibercultura no es otra que la "exforma", un ámbito "donde se desarrollan las negociaciones fronterizas entre lo excluido y lo admitido, entre el producto y el residuo". Lo exformal designa a la "forma atrapada en un procedimiento de exclusión o de inclusión", es decir, "a todo signo transitando entre el centro y la periferia, flotando entre la disidencia y el poder" (2015:11).

En Spam, el problema ontológico de lo real y lo virtual se torna más complejo cuando ingresa al debate el carácter ilusorio de la lengua:

\author{
No entiendo por el acento si el barco es real \\ o si hay un set enorme bajo el agua. \\ Imagino que el set es contaminante, \\ y que los suizos no tenían mucha opción. \\ Los mares de Suiza son como los esquimales de la Antártida, \\ o las montañas de Holanda, o como la nieve de Jamaica, \\ todas ilusiones que sólo existen como ejemplos de lenguaje, \\ como ejemplos de lo peligroso que es \\ que una cosa pueda enunciarse sin existir ni ser tampoco abstracta (18).
}

Los nombres están hechos de "errores de tipeo" o "mutaciones infinitas traducidas por el Google" (Spregelburd, 2016 b: 24) como el de Andreína Potozievna Poco Amarello, 
una operaria de la fábrica de juguetes que graba en muchos idiomas las voces de la muñeca Hiang-Fu (Patrizia, en Italia), a partir de una lista de traducciones de Google. La operaria repite por fonética hasta que "los sonidos cobran vida propia/ y se acomodan a esa boca china como pueden" (Spregelburd, 2016 b: 26), o quizá la operaria confunde sílabas a causa de manchas de té sobre las palabras (26). En escena se muestra al espectador la confusión generada por las malas traducciones del google traslator que envuelven al protagonista en un crimen de la mafia china. Pero esta virtualidad no hace más que replicar, por un lado, la misma irrealidad de la lengua ("Son nervoestimulantes, Cassandra, las palabras", sostiene Monti (31)) y, por otro lado, lo que acontece en el entre de una lengua y otra, o la intraducibilidad de la experiencia:

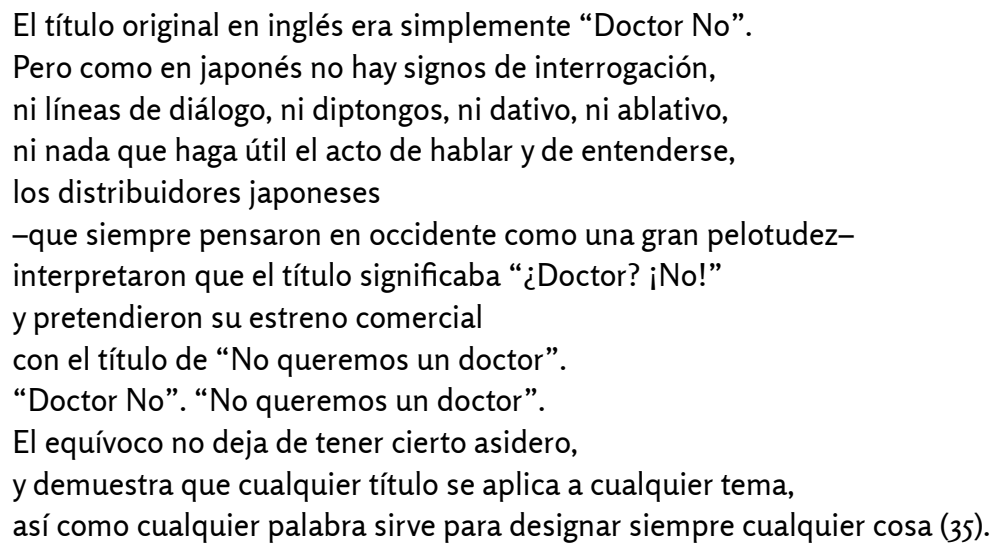

Toda teoría del sujeto, sabemos, involucra necesariamente una teoría del lenguaje; y en el proceso de desubjetivación que se lee en Spam, el lenguaje desempeña un rol fundamental. El universo que aquí se configura no está gobernado por un Dios ni se rige según los ideales platónicos (el mundo inteligible de la metafísica). El lenguaje parecería, por el contrario, destronar a todo $\operatorname{Dios}^{7}$ y producir imágenes de un viviente que ya no guarda ninguna semejanza con la divinidad, porque no hay arquetipo posible ni fundamento trascendente con el que pueda identificarse, sino sombras o fantasmas que son, en definitiva, la imagen de lo humano (Prósperi, 2016). Así, los vínculos en la web multiplican rostros sin nombre o nombres que -como el de Diosno pueden ser pronunciados sin escándalo: lo real es aquí la máscara o, como dirá Badiou en El siglo a propósito de las vanguardias, lo "real", lo "desnudo", es lo que se da directamente en la "máscara" y el "semblante" (Badiou, 2005: 71). Tal pensamiento sobre el lenguaje comprende lo residual e incongruente de este sistema destartalado por la diferencia entre lo propio y lo más otro de lo propio, lo real y lo virtual; en palabras de Bourriaud, lo no asimilable, lo prohibido, lo inutilizable, lo inútil:

Detrás de ese desplegado antieconómico y anticomunicativo se lee el convencimiento de que sólo la experiencia de la existencia pura del lenguaje abre al pensamiento la pura existencia del mundo. Y ésa es la mayor virtud de Spam, que piensa la pura existencia del mundo más allá de la memoria (que se ha perdido), de los nombres (que no designan nada), del sentido (que es totalmente opaco, o ilegible) y del dinero (ese otro lenguaje que se ha vuelto totalmente virtual), a partir de la experiencia pura del lenguaje (teatral y poético) (Link: 2014).

\section{"Lo didascálico: una exforma"}

Proponemos que el estudio de las didascalias de esta pieza puede aportar al análisis del tema del archivo y la construcción de la memoria como instancias claves del proceso de desubjetivación, ya que esta zona del texto teatral -como hemos anticipado- reitera
7. Como afirma el mismo Spregelburd respecto de su Heptalogía: "en el centro (...) no está Dios. Está -creo yo- el lenguaje" (Spregelburd, 2016: 15). 
la figura del entre. Es preciso aclarar que este trabajo dedicado a Spam forma parte de una investigación más amplia sobre los procesos de subjetivación/desubjetivación en la dramaturgia. Dicho proyecto propone pensar el texto teatral como resto y acontecimiento en el acto de irrelación que supone toda lectura (Dalmaroni, 2013), al tiempo que elaborar una intervención crítica respecto de los modos exclusivamente contextualistas, lingüísticos y filológicos de leer el teatro, esto es, elaborar una teoría de la resistencia del teatro a la lectura; ya que, a poco de ser interrogado, el tema se nos presenta como un anudamiento de algunas de las principales constantes del pensamiento (o de la teoría) contemporáneo acerca de -a la vez- el lenguaje y la subjetividad (y la intersubjetividad).

Lo didascálico en tanto huella (Derrida) del texto teatral, donde la voz tiene efectivamente lugar por presencia o ausencia, ya se sabe perdido antes de inscribirse (o excribirse) como corpus, como marca que tiene lugar para registrar lo inimaginable. Se trata de una interrupción o intervalo a partir de dos tipos de entre: 1) entre el texto teatral y la puesta en escena, donde se puede leer lo que el dramaturgo, el lector común y el especializado, proyectan en imágenes de una posible puesta en escena que no es presente; plano fantasmático de la imaginación, potencia de visión o registro de lo que previamente sucedió y se fija luego por escrito, y 2) como interrupción intratextual que abre un entre interno en el corpus del texto teatral. Lo didascálico sería, entonces, dis-curso y corte, una escritura de lo Extremo, siempre fuera de sí: figura límite del texto teatral a nivel teórico y escénico. Es el sitio privilegiado para registrar lo que Szuchmacher define como "hipótesis de representación" (2015: 74-76) o presunción de la materialidad del hecho escénico. Es decir, que lo didascálico puede ser pensado como sinécdoque o lugar de condensación de las marcas dramatúrgicas que remiten "directa o indirectamente a los sistemas de producción teatral particulares de los momentos de la escritura" (2015: 74-76): la organización temporal (actos, cuadros), la cantidad de personajes presentes en cada escena, la concepción del espacio o las formas del lenguaje propiamente dicho, el público que supone y postula, por mencionar los más significativos (2015:74-76). Sin embargo, la expresión de lo no-verbal no sólo se inscribe en la didascalia, ${ }^{8}$ es decir, que no está confinado sólo a esas notas en cursiva o entre paréntesis, ni tan sistemáticamente territorializado como quisieran las lecturas canónicas del teatro que privilegian el aspecto referencial y contextual. Si la hipótesis de representación se configura en la totalidad del texto: ¿qué es lo que se presenta exclusivamente en las didascalias? Más que indicaciones de puesta en escena o instrucciones de interpretación dadas por un autor a sus lectores, proponemos que se trata de inscripciones donde se constituye una poética singular, esto es, -en palabras de Rancière- un acontecimiento poético que resulta próximo a un régimen estético y no representativo (2009).

Lo didascálico modula una voz textual que se reactualiza de manera no calculable: puede presentarse en escena por medio de alguna no-lengua ${ }^{9} \mathrm{o}$, en cambio y a la vez, tener lugar por ausencia. Los intentos de (re)construir una voz a partir de (sus) desechos (correo basura) y de los diversos artefactos tecnológicos y soportes que configuran esta subjetividad siempre mediada o diferida, se modulan en las didascalias de Spam entre la imaginación de un dramaturgo (potencialmente director), el registro de la puesta en la escritura, y una voz otra de tenor poético (un "habla pronunciada no dicha"), todavía en la misma laringe, la lengua, los dientes, sin porvenir. Esta palabra que podría resonar si llegase a ser dicha, permanece siempre "todavia ahí", tragada en el instante sustraído al ser dicha. Una voz, en definitiva, que "no es lenguaje, ni vocablo, ni vocalización, ni vocal", sino diálogo silencioso (Nancy, 2013: 79).

Las figuras del poeta, el director y el actor o performer, suelen estar superpuestas en las obras de Spregelburd. Él mismo plantea su inquietud respecto de este asunto:
8. Las didascalias no garantizan la presencia de un texto destinado a la escena. Como sostiene Szuchmacher, se conocen textos literarios no dramáticos donde se especifican nombres de personajes, se indican lugares donde se desarrolla la acción, se describen sonidos, por ejemplo, los Diálogos de Platón, los Discorsi de Galileo Galilei o algún capítulo del Ulises de Joyce (2015: 75). Por el contrario, algunas obras se consideran teatrales aunque no presenten diálogos ni indicaciones de personajes o de escenografía: materiales que se han llevado una y otra vez a escena como Hamlet Maschine de Heiner Müller.

9. Expresiones artísticas que no se manifiestan por medio de la palabra sino que se corresponden con sistemas visuales, sonoros, de movimiento, etcétera. 
Cuando voy a publicar una obra se me presentan muchos problemas porque tengo por un lado la obra formal, escrita, registrada en Argentores, $y$, por otro el guión de escena, a veces más ilegible. Entonces pienso qué cosas de ese guión necesito modificar en la obra antes de su publicación definitiva, cómo me gustaría que fuera leído. Es una pretensión absurda porque, además, el teatro lo lee muy poca gente. Pero en algún momento uno se pregunta: ¿qué de todo esto que he elegido debería pasar el filtro del tiempo y suponer que será legible dentro de diez, veinte o cincuenta años para no quedar el autor como un salame? En el texto de Apátrida... yo decidí dejar constancia de que, por ejemplo, ciertos textos son dichos por una audio-guía, maquinizados por una serie de grabadores que son operados como bandoneones por los intérpretes; si no lo hiciera, corro el riesgo de que ese texto sea leído sólo de manera literal, cuando ese texto es -además y fundamentalmente- música. ¿Cómo se acota, cómo se anota? (...) no me gustaría que esto sea leído de una manera distorsionada pero, al mismo tiempo, no hay otra manera de leer que no sea la distorsión. ¡Ese mismo texto, dentro de diez años, ya estará distorsionado por su propio entorno! Se trata de un problema insoluble que tampoco se soluciona no operando sobre él. (...) me abruma la sensación de que la versión que queda es sólo una entre tantas, es una especie de casualidad o de capricho momentáneo, mío y de mi tiempo (Spregelburd en Conde, 2013: 73).

Entonces vemos que no se trata de significados acabados que se asocian arbitraria o convencionalmente a ciertos significantes más o menos constantes que se pueden clasificar o tipificar, como lo sugieren las teorías semióticas o lingüísticas del teatro, sino -siguiendo a Lacan - de "efectos" de significación donde una palabra plena (que siempre incluye "el discurso del otro en el secreto de su cifra") reordena las contingencias pasadas dándoles el sentido de las necesidades por venir que el sujeto presentifica (Lacan,1985: 246). Lo didascálico se libera del sujeto (la voz del autor o del director) si lo introducimos en el lenguaje de su deseo, es decir, "en el lenguaje primero en el cual más allá de lo que nos dice de él, ya nos habla sin saberlo, y en los símbolos del síntoma en primer lugar" (282). En Lo que queda de Auschwitz, Agamben retoma una carta que Keats le envía a John Woodhouse, "La confesión vergonzosa", para reflexionar sobre el proceso de desubjetivación del poeta. Insiste en un incesante faltarse a sí mismo para consistir únicamente en la alienación, en la inexistencia, y en la contradicción que supone el enunciado "yo soy un poeta" cuando este es siempre alguien distinto de sí, que está "en lugar de otro cuerpo". La experiencia poética sería la (vergonzosa) experiencia de testimoniar la propia desubjetivación (Agamben, 2005: 118).

En Spam, las didascalias organizan, instruyen y proponen un juego de lectura y expectación que implica un azar aparente (ya en Bizarra había planteado un juego de azar controlado con mayor intervención del público). ${ }^{10}$ No obstante, observaremos también y especialmente la manifestación sintomática de la desubjetivación de esa voz que interrumpe el texto escrito para ser dicho. Citamos ahora dos fragmentos donde se modulan diferentes voces, subjetividades y funciones del lenguaje:

Día 10: Agrande su pene

En primer plano, un calendario de aluminio con sus enormes días ordenados cronológicamente, del 1 al 31.

Fatídico karaoke. Canciones de Dean Martin, fondos de pantalla como posters apocalípticos de oficinas de turismo. En escena, un poco desorientado, se encuentra Monti. Viste un smoking raído y poco convincente. Monti observa los objetos a su alrededor, observa al público, y le gustaría intentar una explicación. Se agarra la nuca con dolor. Luego levanta del suelo una enorme sopladora de hojas y la pone en marcha. Las cosas
10. En el texto se presenta un "Final triste" y un "Final menos triste". En la didascalia se aclara: "Luego se opta por una de las dos escenas que siguen, evidentemente la dos miserables" (Spregelburd: 2008, 506). En función se elegía por medio de una votación de manos alzadas; en algunas ocasiones, comenta el mismo Spregelburd, los actores han manipulado la elección según diversas circunstancias (527-528). 


\begin{abstract}
vuelan sin rumbo. Monti arremete contra el calendario, y las placas con los días caen en total desorden. Monti deja a un lado la sopladora de hojas. Mientras continúa el karaoke, recoge los números del suelo y comienza a reubicarlos en cualquier orden. El sistema para el sorteo de días puede variar, pero el público debe compartir la sensación de que las escenas ocurren al azar. También se podría hacer sorteando los días en un bolillero, como una lotería. El primer número en el calendario es ahora el 10. Monti lo anuncia en voz alta, se lo muestra al público. Es el número de la escena que veremos (1).
\end{abstract}

\title{
Día 24: Una operaria en Nanchang
}

Se trata de un video chino, muy poco explícito. Parece una ópera. Una bailarina china se empeña en contar con movimientos, ademanes y abanicos una historia. Mientras lo hace, leemos subtítulos que tal vez sean sólo una ayuda (o un desvío) para el público occidental. Porque no queda claro si la historia que cuentan los subtítulos es la misma que cuenta en su frenesí la bailarina, o tal vez otra historia cualquiera que nuestro cerebro decide unir, porque así funcionan estas cosas, y la relación entre significado y significante es una farsa sin ley y sin modales. Los subtítulos se proyectan en pausas regulares (26).

En estos tramos didascálicos se pueden advertir al menos las siguientes modulaciones: a) intervenciones clásicas, que hablan de la escena en términos técnicos, teatrales ("En primer plano, un calendario de aluminio", "En escena", "observa a público" (Spregelburd, 2016 b: 6); b) irrupción de lo poético y lo épico ("Fatídico", "como posters apocalípticos de oficinas de turismo", "smoking raído y poco convincente", "le gustaría intentar una explicación", "Las cosas vuelan sin rumbo" (6), "muy poco explícito", "Parece...", "Se empeña en...", "leemos subtítulos que tal vez sean sólo una ayuda (o un desvío", "porque así funcionan estas cosas...") (26); y c) intervenciones de un director que proyecta imágenes y modos de realización escénica o que registra por escrito lo que aconteció previamente en el período de construcción del espectáculo (todo lo referido al sistema para el sorteo de días y la sensación que debe generarse en el público o las hipótesis acerca de la realización, por ejemplo: "Los subtítulos se proyectan en pausas regulares" (26)).

La didascalia indica que Monti observa el calendario y anuncia el nombre del siguiente día: "Es el 7. Los números deben quedar ordenados -idealmente- en el orden que se indica. Se trata de un azar controlado. Pero el público tendrá legítimo derecho a suponer que los números salen realmente al azar" (Spregelburd, 2016 b: 8). En el registro visual de función el actor dice: “Día cuatro. ¡Ay!, qué picardía, estos quedaron al revés. No, porque cronológicamente hubiera sido preferible que les contara...", refiriéndose al día cinco que se ubica antes que el cuatro. Naturalmente el público ríe, puesto que el actor subraya algo evidentemente configurado como sistema: todos los días están desordenados. No obstante, ese índice que hace aparecer de nuevo el artificio sostiene un efecto de verosimilitud respecto del azar gracias a que el performer actúa la imposibilidad de intervenir sobre ese orden que se ha instaurado por casualidad.

Luego, esta voz cercana a la de un Spregelburd director explica que en la versión de estreno ciertas escenas (algunos días) directamente no figuraban en el tablero, puesto que "es importante que no todas las escenas de esta obra se vean: la fuerza de la información faltante, errática e indefinida, debe ser enorme para poder seguir esta historia con facilidad" (8). Entonces el como si no es mero juego aparente, un pseudo-Rayuela o un engaño al espectador, sino que éste se vuelve parte de ese entre: imagina, testifica -como Monti, como la obra misma- la incompletud propia de todos los sujetos involucrados en el hecho teatral, la incompletud propia de la escritura. Como es sabido, la 
tradición teatral es un paradigma de la mirada desde la misma etimología de la palabra griega theatron; por lo tanto, esta didascalia -y lo didascálico, insistimos, siempre es un fuera de sí- viene a testificar, por un lado, el desplazamiento de Spam respecto de la dramaturgia tradicional (eso que Lehmann (1999) piensa como posdramático) y, por otro, que la obra se configura a partir de esos huecos, en el entre de lo visible e invisible. No se trata entonces de un detrás de escena o de episodios que no se muestran y se reponen por medio de diferentes recursos escénicos o dramatúrgicos (a la manera del mensajero o los relatos épicos en la tragedia griega): lo que no se ve o no se dice, falta; y ese blanco o interrupción, es el Sentido mismo, siempre informe y caótico. Hay una parte que es lógica, sostiene el autor, "pero la expectación está lograda a partir del tajo" puesto que se promete un orden atravesado de una realidad compleja donde pareciera que entre un significado y otro no hay nada que los una, logrando una mayor percepción del sentido. La combinatoria de elementos reconocibles (un profesor napolitano, un cuadro de Caravaggio, una estudiante y su tesis) revela una trama innombrable que es emocional ("no hay respuestas lingüísticas para explicarlas" (Spregelburd en Crespo, 2014: 19) así como también ciertos patrones del azar, que el autor suele sistematizar a partir de la teoría del caos. ${ }^{11}$

En la versión definitiva del texto no publicado se colorean con verde frases que en escena Zypce reproduce en varios momentos posteriores a la enunciación en vivo. Tal propuesta nos hace volver a leer esas frases páginas atrás, en lugar de inscribirlas nuevamente en cada repetición. En función la experiencia es, en cambio, inmediata y auditiva. Por lo tanto, el procedimiento pareciera señalar que la escritura no pretende disfrazarse de experiencia, sino que se nombra escritura una y otra vez, como suele ocurrir en la mayor parte de la producción del dramaturgo. Además -y lo que nos resulta más interesante-, aparece en esta didascalia ese improbable escénico (o impensable) que desborda las instrucciones de puesta en escena y la información de tipo contextual o actancial:

\section{Sentado en la vereda, al sol abrasador del mediodía, Monti vende unas muñecas chinas que hablan al apretarles la panza. Las va probando. Las muñecas tienen diversos textos grabados. Textos de la obra que han recogido mal (son las líneas que aparecen en rojo en la obra), frases recicladas, que usan oraciones que se han dicho en otros contextos, combinatoria de sintaxis en puro movimiento, ruidos de fin de los tiempos, restos de palabras talladas entre tantas otras, haikus forzados por chips chinos inestables (61)}

La voz que irrumpe en las siguientes didascalias no es la de Monti, ni la del autor o director; se trata de un registro poético singular que desborda toda concepción dualista y esencial del sujeto, muy próximo a las intervenciones que podemos encontrar en Esperando a Godot de Samuel Beckett (o en otras producciones que la crítica reconoce como teatro del absurdo) donde se evidencia la presencia del espectador no sólo para revelar el artificio en términos estéticos sino también, y sobre todo, para poner en crisis ese entre de la realidad y la ficción en términos escénicos y filosóficos, señalando siempre la divergencia o casilla vacía entre significante y significado, las palabras y las cosas: "Monti: Sí. Yo también. Estoy con un montón de cosas, estoy con... (mira al público) ...gente. Entonces, ¿quedamos así? Perdón, ¿cómo quedamos? (Silencio.) (...) (Le cortaron.) (58)".

En varias oportunidades la inscripción del silencio, además de dar cuenta de algún aspecto dramático, colabora a construir la musicalidad del verso que, como ya se ha mencionado, es el criterio de selección y disposición de lo que será dicho y no dicho en el espectáculo. ¿Cómo traducir a la escena el siguiente pasaje? ¿Cómo estudiarlo desde la semiótica o la teoría de los actos de habla? ¿Es posible que Spregelburd director haya pronunciado estas palabras como indicaciones de actuación para Laura Amalfi, la actriz que filmó el video?:
11. Se trata del estudio de sistemas complejos, siempre imprevisibles, inestables y sensibles a los cambios pequeños en sus condiciones iniciales, que describen la realidad como un conjunto de circunstancias inciertas: una pequeña variación en un punto del planeta genera un posterior efecto considerable en el otro extremo del mismo (Koss en Spregelburd, 2016: 16). 
Periodista: ¿Usted qué imagina que pasó?

La Juguetera no sabe qué responder. Sacude la cabeza. El mundo le parece una bola misteriosa. El tiempo engorda de gravedad y de angustia (21).

La didascalia, este plus o desborde del texto teatral, ingresaría entonces en un sistema heterogéneo y complejo cercano al de la imagen-sintoma: un síntoma aparece, sobreviene, interrumpe el curso normal de la representación de las cosas según una ley que resiste a la observación banal; un resto que se resiste a ser leído porque es del orden de la irrupción de una inminencia. Como la imagen-síntoma, no viene del pasado, sino que, al ser en parte del orden de lo inconsciente, no se puede enmarcar en una noción de temporalidad más que en la del anacronismo. Se trata de algo que se presenta como surgimiento o aparición de un rasgo inesperado, impensable, en la trama de lo representado (Didi-Huberman, 2011).

\section{“Desechos recalcitrantes"}

Para llegar al final del trabajo, retomamos algunas de las hipótesis que hemos tratado de formular. La basura -como el testigo de Auschwitz- sube a escena para testificar que no se puede testificar (Agamben, 2005); es decir, que no hay sujeto de la experiencia y relato de sí que coincida con una lengua y una idea de mundo posible sin que algo de todo esto esté fracturado, roto, desubjetivado. El spam sería entonces una clase de archivo afín a tal concepción del sujeto, pues da cuenta de la falta de correspondencia entre todos estos términos, en otras palabras, porque señala lo más otro de lo propio: "Ni el archivo, ni la imagen, ni la imagen de archivo dejan ver o conocer un Absoluto. Sólo un jirón, un fragmento, un aspecto ínfimo e indivisible: una mónada" que "rompe la concepción histórica" (Didi-Huberman, 2012: 2,7). Si la imagen "arde de memoria" (idem) 2,7 y de realidad es justamente por su ser incompleto $u$ horadado. Las prótesis de la memoria, que serían en esta obra los dispositivos tecnológicos y algunos pocos objetos que el protagonista lleva consigo, intentan sustituir algunos miembros fantasmas, parcial o totalmente perdidos; no sólo rectifican -como toda ortopedia-y vuelven inteligible aquello que se corre de lo normal, sino que también visibilizan u ocultan la basura que pone en acto una imagen de lo humano y su angustia.

Un residuo, anota el diccionario, es lo que cae cuando se fabrica una cosa, y todas las cosas del mundo -para formularlo en términos lacanianos- entran en escena de acuerdo con las leyes del significante (que son heterogéneas respecto del mundo). Primero está el mundo, luego la escena a la que hacemos que suba este mundo. "La dimensión de la escena, en su división respecto del lugar, mundano o no, cósmico o no, donde se encuentra el espectador, está ahí ciertamente para ilustrar ante nuestros ojos la distinción radical entre el mundo y aquel lugar donde las cosas, aun las cosas del mundo, acuden a decirse" (Lacan, 2006: 44). Parecería que Spregelburd, en consonancia con esta tesis de Lacan, propone la escena en tanto dimensión de la historia, puesto que la misma historia tiene un carácter de puesta en escena. Ahora bien, al mundo algo le viene de vuelta de dicha escena; se trata de "residuos superpuestos" en un "depósito de restos de mundos", que se acumulan sin preocuparse por las contradicciones: "Aquello con lo que creemos enfrentarnos en cuanto mundo, ¿no son simplemente restos acumulados, provenientes de la escena cuando se encontraba, por así decir, de gira? (Lacan, 2006: 44). En el lugar del Otro se perfila una imagen tan sólo reflejada de nosotros, falaz en sí misma, pues lo que en ella se evoca no puede aparecer ahí sino que el deseo está relacionado con una ausencia que, a su vez, hace posible una aparición regida por una presencia que está en otra parte. Tal presencia, el objeto a en la función que cumple en el fantasma, gobierna desde donde resulta inaprensible para el sujeto (Lacan, 2006: 55). Como reserva última irreductible de la libido está en 
efecto vinculado a su falta necesaria, allí donde el sujeto se constituye en el lugar del Otro, durante el proceso de significantización (Lacan, 2006: 131). El sujeto sólo existirá a partir del significante, que le es anterior, y que con respecto a él es constituyente. Entre lo dado y lo que tiene lugar surge una "diferencia", "algo que es el resto", "lo irreductible del sujeto": el $a$ es lo que permanece irreductible en la operación total de advenimiento del sujeto al lugar del Otro y ahí es donde adquirirá su función. Es la caída, el objeto perdido (Lacan, 2006: 175).

El spam como figura de la angustia, de lo irreductible de lo real, es un fenómeno de borde, una señal que se produce en el límite del yo cuando éste se ve amenazado por algo que no debe aparecer; en palabras de Lacan: el "resto aborrecido del Otro" que no está en escena, pero que no hace otra cosa más que pedir a cada instante subir a ella para introducir su discurso en aquel que sigue sosteniéndose en la escena (Lacan, 2006: 153). Y la angustia siempre encuentra -en la mayor parte de la producción del dramaturgo- su contrapeso en el humor. Es justamente esa distancia lograda a partir de la escritura y, fundamentalmente, de la interpretación, la que desenmascara e ilumina las cosas que suceden todo el tiempo, pero permanecen fuera del campo de lo visible, es decir, fuera de escena. La basura, entonces, nos hace dirigir la mirada hacia el entre que se constituye en un tópico o tema de la obra de Spregelburd; un dispositivo escénico (lo hemos pensado en relación con la propuesta audiovisual que, agregamos, se resignifica en la propuesta sonora de Zypce: además de equipos convencionales, emplea instrumentos no convencionales, basura industrial, excedentes, juguetes inútiles); y, por último, un principio constructivo de la dramaturgia, especialmente en las didascalias, fenómeno de borde del texto teatral. 


\section{Bibliografía}

"Abuín González, A. (2008). “Teatro y nuevas tecnologías: conceptos básicos”. Signa, $n^{\circ} 17$, pp. 29-56. En: http://bib.cervantesvirtual.com/FichaObra. html?Ref=029456.

»Agamben, G. (2000). Lo que queda de Auschwitz. El archivo y el testigo. España: Pre-textos.

»Agamben, G. (2001). Infancia e historia. Destrucción de la experiencia y origen de la historia. Buenos Aires: Adriana Hidalgo editora.

»Badiou, A. (2003). El ser y el acontecimiento. Buenos Aires: Manantial.

"Badiou, A. (2005). El Siglo. Buenos Aires: Manantial.

»Bahamondes, P. (2015, 14 de enero). "Lo que se dice y se calla: la escuadra argentina que trae Festival Santiago a Mil”. La Tercera, Cultura. Consultado el 20 de noviembre de 2016 en: http://www.latercera.com/noticia/lo-que-se-dicey-se-calla-la-escuadra-argentina-que-trae-festival-santiago-a-mil/

"Blanchot, M. (1977). Falsos pasos. Valencia: Pre-textos.

》 Blanchot, M. (1992). El espacio literario. Madrid: Editorial Nacional.

》Blanchot, M. (2008). La conversación infinita. Madrid: Arena Libros.

"Bourriaud, N. (2015). La exforma. Buenos Aires: Adriana Hidalgo.

»Chapple, F. (ed.) (2008). "La intermedialidad/Intermediality" [Número monográfico]. Cultura, lenguaje y representación, Vol.6, mayo de 2008. Consultado el 6 de octubre de 2016 en: http://www.erevistes.uji.es/index.php/clr/issue/view/5.

»Conde, L. (2013). “¿Quién es nosotros? Encuentro con Rafael Spregelburd”. Estructura Mental a las Estrellas, Año III, $\mathrm{n} \cong 5$, 2013, pp. 70-77.

"Conde, L. (2016). “Modulaciones de la voz en La última cinta de Krapp" en margarit, L. y Montes, E. (eds.). Actas de las Segundas Jornadas de Literatura Inglesa: 110 años del nacimiento de Samuel Beckett. Buenos Aires: Editores Argentinos. ISBN 978889341496.

»Cornago, O. (2004). “El cuerpo invisible: teatro y tecnologías de la imagen”. Arbor. Ciencia Pensamiento y Cultura, marzo-abril de 2004, Vol. 177, n 699/700, pp. 595-610. Consultado el 15 de noviembre en: http://arbor.revistas.csic.es/index. php/arbor/article/viewArticle/597.

»Cornago, O. (2005). Resistir en la era de los medios. Estrategias performativas en literatura, teatro, cine y televisión. Madrid: Iberoamericana Vervuert.

"Crespo, J. I. (2014, 5 de junio). "La creación de una ficción descansa en la muerte”. Llegás a Buenos Aires, Año 10, № 184.

"Dalmaroni, M. (2011). “Lectura, escritura y de-subjetivación: la literatura en algunos textos de Alain Badiou". Pensamiento de los confines 28/29, Buenos Aires: primavera 2011-invierno 2012, pp. 53-62. Disponible en: http://www.lectorcomun.com.

»Davini, S. (2011). “Las dimensiones acústicas del teatro". Presentación del dossier, telondefondo. Revista de Teoría y Crítica Teatral, Año VII, n 13, Julio de 2011.

»Derrida, J. (1998). De la Gramatología. México: Siglo XXI. 
»Derrida, J. (2002). Demarcaciones espectrales: en torno a "Espectros de Marx". Madrid: Akal.

»Didi-Huberman, G. (2011). Ante el tiempo: Historia del arte y anacronismo de las imágenes. Buenos Aires: Adriana Hidalgo.

»Didi-Huiberman, G. (2012). “El archivo arde”. Traducción de Juan Ennis para uso interno de la cátedra de Filología Hispánica, CTCL/UNLP.

"Diéguez, I. (2007). Escenarios liminales. Teatralidad, performances y política. Buenos Aires: Atuel, 2007.

»Huyssen, A. (2006). "La dialéctica oculta: vanguardia-tecnología cultura de masas", en Después de la gran división. Modernismo, cultura de masas, posmodernismo. Buenos Aires: Adriana Hidalgo.

"Koss, N. (2016). “Apología de la desmesura”, “Prólogo” a La estupidez de Rafael Spregelburd. Buenos Aires: Eudeba.

"Lacan, J. (1985). Función y campo de la palabra y del lenguaje en psicoanálisis en Escritos 1. Buenos Aires: Siglo XXI.

"Lacan, J. (2006). El seminario 10. La angustia (1962-1963). Buenos Aires: Paidós.

»Lehmann, H-T. (2013). Teatro posdramático. Murcia/México: CENDEAC/Paso de Gato.

»Link, D. (2014, 20 de abril). "El día después de mañana". Perfil Cultura. Disponible en <http://linkillo.blogspot.com.ar/2014/o4/el-dia-despues-de-manana. html>,

»Nancy, J.-L. (2003). Corpus. Madrid: Arena Libros.

»Ojeda, A. (2017, 17 de enero). "Rafael Spregelburd: 'Me limito a prepararle al espectador una fiesta agridulce'". Consultado el 4 de mayo en <http://www.elcultural.com/noticias/escenarios/Rafael-Spregelburd-Me-limito-a-prepararleal-espectador-una-fiesta-agridulce/10288>.

"Pavis, P. (2001). “Escrituras dramáticas contemporáneas y nuevas tecnologías”. Conjunto, octubre - diciembre de 2001, no 123 . Consultado el 10 de marzo en $<$ http://www.casa.cult.cu/publicaciones/revistaconjunto/123/pavis.htm>.

»Pinta, M. F. (2012). “Happening”, “Performance” y “Tecnoescena”, en Kozak, Claudia (ed.), Tecnopoéticas argentinas. Archivo blando de arte y tecnología. Buenos Aires: Caja Negra.

»Prósperi, G. (2016). “La máquina antropológica como máquina óptica”. Instantes y azares, $N^{\circ} 15-16$, Octubre de 2016. Disponible en <www.instantesyazares. com.ar/article/la-maquina-antropologica-como-maquina-optica/>.

»Rancière, J. (2009). La palabra muda: ensayo sobre las contradicciones de la literatura. Buenos Aires: Eterna cadencia.

»Sánchez, J. A. (2007). La representación de lo real. Artea. Investigación y creación escénica. Consultado el 15 de mayo en <http://www.arte-a.org $\geq$.

"Spregelburd, R. (2008). Bizarra. Una saga argentina. Buenos Aires: Entropía.

» Spregelburd, R. (2016a). La estupidez. Buenos Aires: Eudeba.

»Spregelburd, R. (2016b). Spam. Material de archivo, previo a su publicación.

"Szuchmacher, R. (2015). Lo incapturable. Buenos Aires: Reservoir Books. 